\title{
Combining Ability in Mixtures of Prairie Grass and Clovers
}

\author{
Miguel Jacinto Arturi ${ }^{1 *}$, Mónica Beatriz Aulicino², Oscar Ansín , Gustavo Gallinger ${ }^{1}$, \\ Rodolfo Signorio ${ }^{3}$ \\ ${ }^{1}$ Facultad de Ciencias Agrarias y Forestales, Universidad Nacional de La Plata, Calle 60 y 119 S/N, CC·31 (1900) La Plata, Provincia \\ de Buenos Aires, Argentina; ${ }^{2}$ Instituto Fitotécnico de Santa Catalina, FCAF, UNLP, Garibaldi 3400, (1836) Llavallol, Provincia de \\ Buenos Aires, Argentina; ${ }^{3}$ Estación Experimental J. Hirschhorn, FCAF, UNLP, Calle 66 y 166 S/N, Los Hornos, Provincia de \\ Buenos Aires, Argentina. \\ Email: *genetica@agro.unlp.edu.ar
}

Received July $13^{\text {th }}$, 2012; revised August $10^{\text {th }}$, 2012; accepted August $25^{\text {th }}, 2012$

\begin{abstract}
Our objective was to evaluate the combining ability among cultivars of forage species, commonly sown in temperate regions of Argentina using a short rotation system. Three genetically diverse cultivars of prairie brome grass (Bromus catharticus, $c v$ Copetona, $c v$ Ñandú and $c v$ Tango), a white clover cultivar (Trifolium repens, $c v$ Lucero) and a red clover cultivar (T. pratense, $c v$ Tropero) were evaluated. A randomized complete block design experiment was established in 2005. The treatments included five monocultures and ten binary mixtures. The experiment was harvested 6 times over an 18-month period. Cumulative dry matter yield $\left(\mathrm{kg} \cdot \mathrm{ha}^{-1}\right)$ was calculated as the sum of the six individual harvests. Diallel analysis provided estimates of the general combining ability (GCA) and specific combining ability (SCA). Red clover in monoculture and mixtures produced the highest yields, with significant positive GCA effects $(P<0.01)$. Lucero white clover, and Copetona and Tango prairie grasses had significant negative GCA effects $(P<0.05)$. In mixtures, red clover with each of the three grass cultivars and white clover with Tango had significant and outstanding SCA effects $(P<0.01)$. Grass/grass mixtures and the legume/legume mixture showed non-significant SCA effects, while the grass/legume mixtures generally had higher yield than either component sown as a monoculture $(P<0.01)$. Given the short-term nature of this study, we must limit our inference to short-term pastures ( $<2$ years). Under these conditions, red clover had the best combination with prairie brome grass.
\end{abstract}

Keywords: Bromus catharticus; Trifolium repens; T. pratense; Grass/Legume Mixtures; Dry Matter Yield; Argentina

\section{Introduction}

Sowing grass/legumes mixtures, as pasture for livestock, is a common practice in the temperate regions including most of the renovated prairies in the Argentinean pampas. Acceptance of these forage mixtures is based on the apparent advantages offered by the association of different genotypes or species that influence the performance temporal stability of yield and forage quality [1-4]. Species that have different physiological and/or morphological characters may complement better and make better use of the nutritional resources. A practical example is the atmospheric nitrogen fixation by legumes in favor of grasses; the introduction of legumes in mixed pastures increases forage yield and quality and reduces the nitrogen fertilizer requirement of the grass $[5,6]$.

Intra-specific or varietal mixtures have been widely used in subsistence farming systems, especially in cereals

\footnotetext{
*Corresponding author.
}

and other crops [7]. Cultivation of mixed grass/legume grassland has increased and continues to grow because there are a number of potential advantages in comparison to monocultures. Mixtures extend harvest and income flow, provide diversity of feed and reduce disease. The yield of grass/legume mixtures is more stable under changing environmental conditions than monocultures. This results in higher mean biomass production in comparison to their components grown in monoculture. Biomass yields in mixtures are rarely lower than the poorer component [1].

In Argentina, there are a range of recommended grass/ legume mixtures, starting from binary to more complex combinations in different areas of livestock production [8]. These recommendations are mainly based on accumulated knowledge from experimental stations and in some cases supported by regional trials of various mixtures. Competition or compatibility among species varies with the environment and is influenced by key factors such as 
climate, soil and grazing management systems [4,9].

A methodology commonly used in quantitative gentics which involves the diallel crossing analysis was adapted to asses the combining ability in a set of binary mixtures of forage or other crop species [10,11]. It applies the concepts of diallel crossing systems used by geneticists $[12,13]$, and later adapted to the study of binary mixtures of forages or other crop species $[14,15]$. In this method each mixture is compared to an F1 and their parents to monocultures.

The aim of this study is to evaluate the combining ability among cultivars of three species recommended for agricultural soils in the valley of the Salado river, prairie brome grass (Bromus catharticus Vahl.) and two legumes, white clover (Trifolium repens L.) and red clover ( $T$. pratense L.). Under the ecological conditions of these soils, the grass usually behaves as an annual, the red clover as a biennial and the white clover as a perennial [16]. The three brome cultivars included in this study have different growth habits, which will allow exploring the effect of that trait on their combining ability in intraspecific mixtures. Plant structure, leaf area index and other morphological characters are often affected by plant density and height and frequency of defoliation $[17,18]$. Since the method of analysis includes all the binary combinations among the cultivars tested, it was possible to analyze the grass/legume mixtures as well as the combinations of the grass/grass and legume/legume mixtures. The experiment was planned as a short-rotation system which comprises 2 to 3 years cycles and which allows cattle production to be alternated with cereal and oil crops. This system is frequently adopted in Argentinean humid pampas due to the advantage of maintaining soil fertility and improving soil structure.

\section{Materials and Methods}

\subsection{Plant Materials}

Three brome grass cultivars were used (cvs Copetona, Ñandú and Tango). Copetona, developed by FCAF, was selected from populations collected at sites with soils with high clay content in the north of Buenos Aires province. Cultivar Copetona is characterized as a semierect type with wide leaf blades, early production during winter and early spring. Cultivar Ñandú was also developed by FCAF, and selected from populations collected in subhumid environments. This cultivar has an erect growth habit with medium blade width, a high dry matter yield per hectare and good stability. Cultivar Tango was developed by Gentos S. A. and has a prostrate growth habit, with broader leaves and an outstanding tillering capacity.

Two legume cultivars were used (Lucero white clover and Tropero red clover). Lucero has erect growth habit, large leaflets, and thick stolons, is well adapted to fertile soils, and has peak production in spring and autumn.
Tropero, was bred in USA, with high re-growth rates, quick establishment in the field and outstanding summer production.

\subsection{Experiment Design}

The experiment was conducted at the Experimental Station J. Hirshhorn of the Facultad de Ciencias Agrarias y Forestales (FCAF), Los Hornos, La Plata at Buenos Aires, Argentine $\left(34^{\circ} 55^{\prime} \mathrm{S}, 57^{\circ} 57^{\prime} \mathrm{W}\right)$. The average annual temperature ranges from a high of $23.5^{\circ} \mathrm{C}$ in January to a low of $7^{\circ} \mathrm{C}$ in July. The annual rainfall varies between 800 and $1000 \mathrm{~mm}$ per year, with precipitation normally higher in autumn and spring. The soil was classified as Argiudol [19].

A randomized block design with two replications was used. Treatments comprised three grass cultivars and two legume cultivars, grown in monocultures and in the ten possible binary mixtures (a total of 15 treatments). Plots were composed of six $6.0 \mathrm{~m}$ long rows with $0.20 \mathrm{~m}$ between each row. In the case of the mixture plot, the two cultivars were sown in alternate rows. The experiment was sown in the second half of April 2005, with a density equivalent to $10 \mathrm{~kg} \cdot \mathrm{ha}^{-1}$ of prairie grass, $3 \mathrm{~kg} \cdot \mathrm{ha}^{-1}$ of red clover and $1.5 \mathrm{~kg} \cdot \mathrm{ha}^{-1}$ of white clover. Legume seeds were inoculated with the appropriate Rhyzobium. The experiment covered a biennial cycle, from April 2005 to September 2006. Plots were harvested to a $5 \mathrm{~cm}$ stubble height. The defoliation regimen is intended to provide an estimation of yield which could be apply for different production systems. To ensure consistency the timing of the harvests was based on the prairie grass stage of maturity. When the prairie grass was beginning to flower, clovers were often still in vegetative stage. Six dry matter yield harvests were made during the trial, 6 September 2005, 15 October 2005, 2 December 2005, 28 February 2006, 8 May 2006, and 5 September 2006. To avoid the border effect, only the four central rows were harvested along a length of $4 \mathrm{~m}$, giving a net plot area of $3.2 \mathrm{~m}^{2}$. Then, the unharvested forage from the borders was cut to a same height to promote even re-growth. At each harvest the herbage was weighed and a $200 \mathrm{~g}$ sub-sample was dried for 72 hours in a forced-air dryer at $70^{\circ} \mathrm{C}$ and used to calculate dry matter yield per hectare (DMY, $\mathrm{kg} \cdot \mathrm{ha}^{-1}$ ) for each harvest. Cumulative dry matter yield (CDMY, $\mathrm{kg} \cdot \mathrm{ha}^{-1}$ ) was calculated and analyzed as the sum of the six individual harvests.

\subsection{Statistical Analysis}

Cumulative dry matter yield was analyzed as a split plot design. Fifteen treatments were considered as main plot and six harvest dates as subplots. After registering a significant $(P<0.05)$ treatment $\times$ harvest interaction, data from each harvest were analyzed separately using a one-way ANOVA [20]. The least significant difference 
(LSD) test was used to compare means between treatments. Estimates of general combining ability (GCA) and specific combining ability (SCA) were calculated for CDMY $\left(\mathrm{kg} \cdot \mathrm{ha}^{-1}\right)$. We applied the procedure proposed by [13], corresponding to Method II, Model I, whose mathematical expression is:

$$
X_{i j}=m+G_{i}+G_{j}+S_{i j}+\varepsilon_{i j}
$$

where, $X_{i j}$ : average value of each combination; $m$ : the overall mean test; $G_{i}$ and $G_{j}$ : general combining ability (GCA) effects of each component; $S_{i j}$ : specific combining ability (SCA) effects of each combination; $\varepsilon_{i j}$ : experimental error. The GENES program [21] was used for the analysis of variance and the estimation of GCA and SCA effects. In binary mixtures, the GCA of a species or cultivar was calculated as the overall mean of all combinations that involved that species or cultivar, while the SCA is the deviation of the performance of a particular combination of species or cultivars with respect to the expected value $[11,15]$. SCA measured the interaction between two cultivars for each mixture.

The diallel analysis enabled estimation of the combining ability effects of binary mixtures for DMY. The adaptation of this methodology to the study of forage mixtures is useful to determine competition degree between species or cultivars and identify the best combinations. [11] described different situations: 1) When the effect of $\mathrm{SCA}=0$, the contribution of each species in the mixture is equal to the expected share and indicates competition between species having similar claims for the same resources; 2) When the effect of the SCA $>0$, the contribution of each species in the mixture is greater than the expected share, and denotes compatibility between species because each species require different resources; and 3) When the effect of the SCA $<0$, the contribution of each species is smaller than the expected share, and suggests an incompatibility between species because each species interacts with the other.

\section{Results and Discussion}

Rainfall at the Experiment Station (FCAF) was 50\% lower than normal from September to December 2005, while rainfall was $35 \%$ over average during the months of January and February 2006 (Table 1). Considering the physiological and morphological characteristics of grasses and red clover, respectively, it was likely that both, the spring rainfall deficit and summer heavy rainfall, would negatively affect prairie grass but could have a positive effect on the legumes. The analysis of variance revealed a significant treatment $\times$ harvest interaction $(P<0.05)$ (results no presented). This result was expected due to the differences in growth pattern of the species being studied. For this reason, dry matter yield (DMY) was analyzed separately for each harvest (Table 2).
Table 1. Climatic characterization of the 18 months of evaluation (2005/06) from sowing to last harvest. Monthly mean temperature $\left({ }^{\circ} \mathrm{C}\right)$ and monthly total precipitation $(\mathrm{mm})$.

\begin{tabular}{ccccccc}
\hline & $\begin{array}{c}\text { T 2005 } \\
\left({ }^{\circ} \mathrm{C}\right)\end{array}$ & $\begin{array}{c}\mathrm{T} 2006 \\
\left({ }^{\circ} \mathrm{C}\right)\end{array}$ & $\mathrm{TN}\left({ }^{\circ} \mathrm{C}\right)$ & $\begin{array}{c}\text { P 2005 } \\
(\mathrm{mm})\end{array}$ & $\begin{array}{c}\text { P 2006 } \\
(\mathrm{mm})\end{array}$ & $\mathrm{PN}(\mathrm{mm})$ \\
\cline { 2 - 7 } January & & 22.6 & 24.2 & & 137.5 & 105.4 \\
February & & 22.4 & 23.1 & & 167.0 & 105.0 \\
March & & 18.5 & 20.9 & & 98.1 & 108.9 \\
April & 14.8 & 16.2 & 16.1 & 69.4 & 57.2 & 84.4 \\
May & 12.8 & 11.1 & 13.9 & 23.6 & 10.2 & 86.7 \\
June & 12.2 & 10.8 & 10.9 & 66.2 & 66.0 & 55.3 \\
July & 10.5 & 11.9 & 10.5 & 69.8 & 55.0 & 64.2 \\
August & 10.9 & 10.8 & 11.7 & 90.0 & 30.5 & 55.6 \\
September & 11.8 & 12.7 & 13.9 & 57.8 & 27.3 & 71.1 \\
October & 14.8 & & 16.8 & 44 & & 101.6 \\
November & 20 & & 19.6 & 55.6 & & 100.6 \\
December & 19.6 & & 22.9 & 92.4 & & 79.9 \\
\hline
\end{tabular}

T 2005: Monthly mean temperature in 2005; T 2006: Monthly mean temperature in 2006; TN: Monthly mean temperature averaged ten years; P 2005: Monthly total precipitation in 2005; P 2006: Monthly total precipitation in 2006; PN: Monthly total precipitation averaged 10 years.

Table 2. Means for dry matter yield (DMY) per harvest and cumulative dry matter yield (CDMY) (in $\mathrm{kg} \mathrm{ha}^{-1}$ ) for mixtures and monocultures in pure stand and the mixtures of three prairie grasses (C: Copetona; Ñ: Nandú; T: Tango), and two legumes (R: red clover Tropero; W: white clover Lucero) grown in a short rotation system (2005/06).

\begin{tabular}{|c|c|c|c|c|c|c|c|}
\hline \multirow{2}{*}{$\begin{array}{l}\text { Name of } \\
\text { cultivars }\end{array}$} & \multicolumn{6}{|c|}{ DMY per harvest $\left(\mathrm{kg} \cdot \mathrm{ha}^{-1}\right)$} & \multirow{2}{*}{$\begin{array}{c}\mathrm{CDMY} \\
\left(\mathrm{kg} \cdot \mathrm{ha}^{-1}\right)\end{array}$} \\
\hline & 1 & 2 & 3 & 4 & 5 & 6 & \\
\hline \multicolumn{8}{|c|}{$\times 10^{3}$} \\
\hline $\mathrm{C}$ & 2.264 & 1.671 & 1.239 & 1.473 & 549 & 320 & 7.518 \\
\hline$\tilde{N}$ & 1.889 & 1.806 & 1.435 & 1.809 & 628 & 654 & 8.222 \\
\hline $\mathrm{T}$ & 1.372 & 1.406 & 1.075 & 1.101 & 822 & 399 & 6.176 \\
\hline $\mathrm{R}$ & 182 & 1.009 & 1.979 & 3.782 & 1.922 & 1.550 & 10.428 \\
\hline $\mathrm{W}$ & 177 & 775 & 1.726 & 1.744 & 1.772 & 692 & 6.888 \\
\hline CÑ & 1.545 & 1.373 & 1.083 & 1.543 & 778 & 496 & 6.820 \\
\hline $\mathrm{CT}$ & 1.907 & 1.412 & 1.157 & 1.377 & 471 & 400 & 6.726 \\
\hline ÑT & 1.790 & 1.645 & 1.063 & 1.681 & 937 & 303 & 7.421 \\
\hline $\mathrm{CR}$ & 974 & 1.032 & 2.007 & 3.517 & 2.022 & 2.094 & 11.647 \\
\hline $\mathrm{CW}$ & 786 & 1.665 & 1.383 & 1.748 & 2.000 & 834 & 8.418 \\
\hline ÑR & 962 & 1.722 & 1.923 & 4.444 & 1.606 & 1.872 & 12.529 \\
\hline$\tilde{N} W$ & 988 & 1.229 & 1.316 & 1.894 & 1.643 & 1.079 & 8.150 \\
\hline TR & 1.030 & 1.662 & 1.769 & 4.006 & 1.468 & 2.424 & 12.361 \\
\hline TW & 799 & 1.148 & 1.432 & 2.110 & 1.743 & 1.818 & 9.052 \\
\hline RW & 121 & 843 & 1.970 & 4.357 & 1.372 & 1.882 & 10.547 \\
\hline LSD (0.05) & 645 & 1.101 & 452 & 1.147 & 589 & 854 & 3.014 \\
\hline$F(0.05)$ & $* *$ & NS & ** & ** & $* *$ & $* *$ & \\
\hline \multirow{2}{*}{ Means } & 1.119 & 1.360 & 1.504 & 2.439 & 1.316 & 1.121 & 8.859 \\
\hline & c & b c & $\mathrm{b}$ & $\mathrm{a}$ & b c & C & \\
\hline
\end{tabular}

Critical value for comparison within harvest and their significance levels for Least Square Differences (LSD) and Fisher's test for a randomized complete block (F). Comparison between harvests, values followed by the same letters are not significantly different at $P<0.05$ by Tukey test. NS: Non significant; ${ }^{*}$, ** : significant at $P<0.05$ and $P<0.01$, respectively. 
DMY were significantly different across harvests $(P<$ 0.05 ), with summer harvest (4th) significantly higher due to red clover contribution to monoculture and mixtures (Table 3). Other authors have pointed out that cool-season grasses make a great contribution to forage yield in binary mixtures early in the season [22]. In our trial the herbage volume of each cut through to late summer increased as the result of the progressive contribution of clovers which compensated for the decline of brome cultivars in their post-reproductive stage. After third cut, red clover and its mixtures with Ñandú and Copetona outperformed most treatments $(P<0.05)$. The proportion of brome in grass/legume mixtures was about $85 \%$ and $90 \%$ during the first harvest but decreased steadily to $75 \%$ during the second harvest and to approximately $50 \%$ by third harvest. Low clover growth rate, especially for white clover, affected initial harvests possibly due to its low competitive ability for light and low stolon density during its establishment [23]. In binary mixtures, white clover establishment is affected by grass density and maturity, a reduced sward density and early maturity would probably increase compatibility [24-27].

Our results showed that the grass growth habits influenced over the compatibility. The highest white clover CDMY was with Tango mixture (Table 3). In white clover/red clover mixture, red clover predominance of $60 \%$ over white clover was observed during the first year. In the second year this proportion began to reverse as red clover reached the end of a life cycle whereas white clover continued growing because it is more perennial. In the second year brome grass contribution to forage production in mixtures declines in Copetona and Tango cultivars, but less in Ñandú which can persist for two years under favorable conditions (Table 3).

The GCA for CDMY is very strong $(P<0.01)$ for red clover, while GCA was negative for all other species (Tables 3 and 4). Red clover GCA was closely related to its productive potential, showing a good ability to integrate successfully in binary mixtures with brome grass cultivars, overall four of the 6 grass/legume combinations showed significant GCA for CDMY (Table 4) while none of the grass-grass or legume-legume mixtures resulted in a positive and significant GCA, and in fact were often negative, for CDMY. This emphasizes the important contribution that legumes make to total pasture performance and to the sustainability of these short-term rotations on the Argentinian pampas. The cumulative dry matter yield (CDMY) of grass/clover mixtures exceeded monocultures in $24 \%$ on average, reinforcing the benefits of mixed pastures.

The significantly high SCA effect $(>0)$ for grass/clover mixtures confirms that components contribution to the mixture was higher than expected on the basis of their yield in monoculture. Since the Experiment Station soil is poor in $\mathrm{N}_{2}$ content, this non-competitive interaction is probably mainly due to $\mathrm{N}$ fixation by clovers benefiting the companion brome grass $[28,29]$. However, although there is no doubt about the effect of nitrogen fixed by the clovers, other factors such as light interception, cut frequency and height could also influence mixture yield.

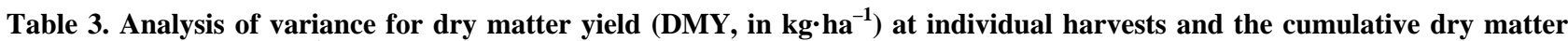
yield (CDMY, in $\mathrm{kg} \cdot \mathrm{ha}^{-1}$ ) for mixtures and monocultures of brome grass and clovers grown over a short rotation system (2005/06). Degree freedoms, means squares and signification levels calculated with Fisher's test for a randomized complete block design.

\begin{tabular}{|c|c|c|c|c|c|c|c|c|}
\hline \multicolumn{9}{|c|}{ DMY per harvest $\left(\mathrm{kg} \cdot \mathrm{ha}^{-1}\right)$} \\
\hline & df & 1 & 2 & 3 & 4 & 5 & 6 & CDMY $\left(\mathrm{kg} \cdot \mathrm{ha}^{-1}\right)$ \\
\hline \multicolumn{9}{|c|}{$\times 10^{3}$} \\
\hline TREA TMENT & 14 & $895^{* *}$ & $229 \mathrm{~ns}$ & $257^{* *}$ & $2.873^{* *}$ & $628^{* *}$ & $1.098^{* *}$ & $9.086^{* *}$ \\
\hline Mixtures & 9 & $561^{* *}$ & $185 \mathrm{~ns}$ & $280^{* *}$ & $3.151^{* *}$ & $541^{* *}$ & $1.231^{* *}$ & $10.060^{* *}$ \\
\hline 1) $G-L$ & 5 & $21 \mathrm{~ns}$ & $188 \mathrm{~ns}$ & $178^{* *}$ & $2.774^{* *}$ & $99 \mathrm{~ns}$ & $742^{*}$ & $8.289^{* *}$ \\
\hline 2) G-G, L-L & 3 & $1.368^{* *}$ & $229 \mathrm{~ns}$ & $381^{* *}$ & $4.016^{* *}$ & $282^{*}$ & $1.111^{* *}$ & $6.517 \mathrm{~ns}$ \\
\hline 1) vs 2) & 1 & $837^{* *}$ & $40 \mathrm{~ns}$ & $491^{* *}$ & $2.444^{* *}$ & $3.529^{* *}$ & $4.031^{* *}$ & $29.540^{* *}$ \\
\hline Pure stands & 4 & $1.858^{* *}$ & $380 \mathrm{~ns}$ & $267^{* *}$ & $2.180^{* *}$ & $861^{* *}$ & $481 \mathrm{~ns}$ & $5.311 \mathrm{~ns}$ \\
\hline Mixtures vs. pure stands & 1 & $50 \mathrm{~ns}$ & $10 \mathrm{~ns}$ & 3 ns & $3.138^{* *}$ & $470^{*}$ & $2.370^{* *}$ & $15.410^{*}$ \\
\hline GCA & 4 & $2.942^{* *}$ & $463 \mathrm{~ns}$ & $757^{* *}$ & $7.979^{* *}$ & $1.388^{* *}$ & $2.188^{* *}$ & $19.993^{* *}$ \\
\hline SCA & 10 & $76 \mathrm{~ns}$ & $135 \mathrm{~ns}$ & $57 \mathrm{~ns}$ & $831^{* *}$ & $324^{* *}$ & $664^{* *}$ & $4.725 \mathrm{~ns}$ \\
\hline ERROR & 14 & 92 & 264 & 45 & 290 & 76 & 161 & 2.004 \\
\hline
\end{tabular}

G-L: Grass-legume mixture; G-G: Grass-grass mixture; L-L: Legume-legume mixture; GCA: general combining ability; SCA: specific combining ability. ns: Non significant; ${ }^{*},{ }^{* *}$ : significant at $P<0.05$ and $P<0.01$, respectively. 
Table 4. General combining ability (GCA, Values on the matrix diagonal) and Specific combining ability (SCA; values outside the matrix diagonal) effects for Cumulative dry matter yield $\left(\mathrm{kg}^{\circ} \mathrm{ha}^{-1}\right)$ of monocultures in pure stand and mixtures of three prairie grasses (Copetona, Nandú and Tango), and two legumes (white clover Lucero and red clover Tropero) grown in a short rotation system (2005/06).

\begin{tabular}{|c|c|c|c|c|c|}
\hline Names of Cultivars & Copetona & Ñandú & Tango & Lucero & Tropero \\
\hline Copetona & $-645^{* *}$ & $-1.139^{*}$ & $-739 \mathrm{~ns}$ & $663 \mathrm{~ns}$ & $1.320^{* *}$ \\
\hline Ñandú & & $-257 \mathrm{~ns}$ & $433 \mathrm{~ns}$ & $7 \mathrm{~ns}$ & $1.814^{* *}$ \\
\hline Tango & & & $-750^{* *}$ & $1.402^{* *}$ & $2.139^{* *}$ \\
\hline Lucero & & & & $-460^{*}$ & $35 \mathrm{~ns}$ \\
\hline Tropero & & & & & $2.111^{* *}$ \\
\hline
\end{tabular}

ns: Non significant; ${ }^{*},{ }^{* *}$ : significant at $P<0.05$ and $P<0.01$, respectively. GCA, SCA: General and specific combining ability, respectively.

In mixtures of brome grass cultivars a favorable intra-specific complementation could be expected due to complementarily of morphological and/or physiological characteristics [30]. Mixtures of genotypes of the same species have been proposed in cereals for increasing grain yield to provide greater capacity to adjust to changing environmental conditions [31,32]. In our experiment we examined the possible complementation of cultivars having different genetic origin and different growth habits. Ñandú shows distinctly erect growth habit, Copetona has semi-erect habit and Tango is described as having semi-prostrate growth. The results showed that the three brome grass mixtures had neutral or negative SCA effects, particularly Copetona and Ñandú mixture $(P<$ $0.05)$. In this case, as opposed to prairie grass-clover mixtures, the SCA value below zero suggested incompatibility between cultivars due to com- petition for the same resources or to allelopathic effects. This type of reaction, also named "autotoxicity", in which interferences between genotypes of the same species are produced, has been found in cereals and other species [15, 33]. Apparently, brome grass growth habit had no influence on results. Although the erect cultivar Ñandú produced the highest mixtures and monocultures yields, no significant differences in CDMY with the other two cultivars were found.

The SCA effects of the white clover/red clover inter-specific mixture, were not significant (Table 4), and this neutral effect between the two components $(\mathrm{SCA}=0)$ suggest this combination is compatible with respect to their resource requirements. Although this mixture is unlikely to be of practical interest, its compatibility is useful for possible inclusion in more complex forage mixtures. Higher complexity would not guarantee production increase, but it would influence on temporal stability of the mixture [34].

Most forage species are destined to be predominantly sown in mixed pastures, and therefore it would be advis- able to evaluate the competitive ability of advanced breeding lines and of new cultivars in the process of diffusion, testing them in mixtures $[35,36]$. Diallel design or factorial combination experiments, such as those performed by [37] with white clover cultivars, would provide valuable information to develop forage mixtures on more solid foundations.

\section{Acknowledgements}

Commercial cultivars seed used in this research were kindly provided by GAPP semillas S.A. and Gentos S.A, Argentina. Anonymous suggestions are acknowledged. The authors thank Ing. Marcelo Asborno and Ing. Martín Pardi for providing the climate data.

\section{REFERENCES}

[1] B. R. Trenbath, "Biomass Productivity of Mixture,” $A d$ vance in Agronomy, Vol. 26, 1974, pp. 177-210. doi:10.1016/S0065-2113(08)60871-8

[2] B. Sleugh, K. J. Moore, J. R. George and E. C. Brummer, "Binary Legume-Grass Mixtures Improve Forage Yield, Quality and Seasonal Distribution,” Agronomy Journal, Vol. 92, No. 1, 2000, pp. 24-29. doi:10.2134/agronj2000.92124x

[3] J. F. Guay, "Compatibility, Yield and Quality of Matua Prairie Grass (Bromus Willdenowii Kunth) with Legumes,” M.S. Thesis, Virginia Politechnic Institute, 2001, p. 85.

[4] E. Sturludóttir, "Forage Quality and Yield in Grass-Legume Mixtures in Northern Europe and Canada,” M.S. Thesis, University of Iceland, Reykiavik, 2011, p. 62.

[5] S. K. A. Danso, S. Curbelo, C. Labandera and D. Pastorini, "Herbage Yield and Nitrogen-Fixation in a Triple Species Mixed Sward of White Clover, Lotus and Fescue,” Soil Biology and Biochemistry, Vol. 23, No. 1, 1991, pp. 65-70. doi:10.1016/0038-0717(91)90163-E

[6] D. Nyfeler, O. Huguenin-Elie, S. Mattias, E. Frossard and A. Luscher, "Grass-Legume Mixtures Can Yield More Nitrogen than Legume Pure Stands Due to Mutual Stimulation of Nitrogen Uptake from Symbiotic and Non-Symbiotic Sources," Agricultural Ecosystem Environments, Vol. 140, No. 1-2, 2011, pp. 155-163.

doi:10.1016/j.agee.2010.11.022

[7] J. B. Smithson and J. M. Lenné, "Varietal Mixture: A Viable Strategy for Sustainable Productivity in Subsistence Agriculture,” Annals of Applied Biology, Vol. 128, No. 1, 1996, pp. 127-158. doi:10.1111/j.1744-7348.1996.tb07096.x

[8] J. Carrillo and M. de Pasturas, "Pastures Management," Experimental Station, INTA, Balcarce, 2003, p. 55.

[9] L. M. Lauriault and R. E. Kirksey, "Yield and Nutritive Value of Irrigated Winter Cereal Forage Grass-Legume Intercrops in the Southern High Plains, USA,” Agronomy Journal, Vol. 96, No. 2, 2004, pp. 352-358. doi:10.2134/agronj2004.0352

[10] N. F. Jensen and W. T. Federer, "Competing Ability in 
Wheat," Crop Science, Vol. 5, 1965, pp. 449-452. doi:10.2135/cropsci1965.0011183X000500050022x

[11] T. L. Springer and R. L. Gillen, "Combining Ability of Binary Mixtures of Introduced, Cool- and Warm-Season Grasses and Legumes," Crop Science, Vol. 47, No. 6, 2007, pp. 2540-2546. doi:10.2135/cropsci2006.12.0773

[12] G. F. Sprague and L. A. Tatum, "General vs. Specific Combining Ability in Single Crosses of Corn,” Agronomy Journal, Vol. 34, No. 10, 1942, pp. 923-932. doi:10.2134/agronj1942.00021962003400100008x

[13] B. Griffing, "Concept of General and Combining Ability in Relation to Diallel Crossing Systems," Australian Journal of Biological Science, Vol. 9, No. 4, 1956, pp. 63-93.

[14] E. R. Gallandt, S. M. Dofing, P. E. Reisenauer and E. Donaldson, "Diallel Analysis of Cultivar Mixtures in Winter Wheat,” Crop Science, Vol. 41, No. 3, 2001, pp. 792-796. doi:10.2135/cropsci2001.413792x

[15] T. L. Springer, G. E. Aiken and R. W. Mcnew, "Combining Ability of Binary Mixtures of Native Warm-Season Grasses and Legumes," Crop Science, Vol. 41, 2001, pp. 818-823. doi:10.2135/cropsci2001.413818x

[16] J. Maddaloni and L. Ferrari, "Forages and Pastures from Humid Temperate Ecosystem of Argentina,” 2nd Edition, INTA-UNLZ, Argentine, 2005, p. 522.

[17] R. J. Haynes, "Competitive Aspects of the Grass-Legume Association," Advances in Agronomy, Vol. 33, 1980, pp. 227-261. doi:10.1016/S0065-2113(08)60168-6

[18] P. Nurjaya, "Genotype and Environmental Adaptation as Regulators of Competitiveness," In: P. G. Tow and A. Lazenby, Eds., Competition and Succession in Pastures, CABI Publishing, Wallingford, 2001, p. 462.

[19] J. W. Lanfranco, “Soil of the Experimental Station," Facultad de Agronomía, Argentina, 1986, p. 20.

[20] R. G. D. Steel and J. H. Torrie, "Principles and Procedures of Statistics," 2nd Edition, McGraw-Hill, New York, 1980, p. 632.

[21] C. D. Cruz, "Program 'Genes'. Windows version for Genetics and Statistics Computations," UFV, Viçosa, 2001, p. 648.

[22] J. D. Berdahl, J. F. Karn and J. R. Hendrickson, "Dry Matter Yields of Cool-Season Grass Monocultures and Grass-Alfalfa Binary Mixtures,” Agronomy Journal, Vol. 93, 2001, pp. 463-467. doi:10.2134/agronj2001.932463x

[23] J. Frame, J. F. L. Charlton and A. S. Laidlaw, “Temperate Forage Legumes,” CAB International, Wallingford, 1998, p. 327.

[24] R. F. Gooding, J. Frame and C. Thomas, "Effects of Sward Type and Rest Periods from Sheep Grazing on White Clover Presence in Perennial-Ryegrass-White Clover Association,” Grass and Forage Science, Vol. 51, No. 2, 1996, pp. 180-189. doi:10.1111/j.1365-2494.1996.tb02052.x

[25] M. A. Sanderson and G. F. Elwinger, "Grass Species and Cultivar Effects on Establishment of Grass-White Clover
Mixtures,” Agronomy Journal, Vol. 91, No. 6, 1999, pp. 889-897. doi:10.2134/agronj1999.916889x

[26] A. Deak, M. H. Hall, M. A. Sanderson and D. D. Archibald, "Production and Nutritive Value of Grazed Simple and Complex Forage Mixtures," Agronomy Journal, Vol. 99, No. 3, 2007, pp. 814-821. doi:10.2134/agronj2006.0166

[27] B. E. Frankow-Lindberg, M. Halling, M. Hoglind and M. Forkman, "Yield and Stability of Yield of Singled- and Multi-Clover Grass-Clover Swards in Two Contrasting Temperate Environments," Grass and Forage Science, Vol. 64, No. 3, 2009, pp. 236-245. doi:10.1111/j.1365-2494.2009.00689.x

[28] J. A. Lynd, E. A. Hanlon and G. V. Odell, "Soil Fertility and Defoliation Effects with Arrow Leaf Clover and Nitrogen Fertilization Equivalent of Crimson-Arrowleaf Clover Combination,” Agronomy Journal, Vol. 76, No. 1, 1984, pp. 13-16. doi:10.2134/agronj1984.00021962007600010004x

[29] I. Rhodes, "Competition between Herbage Grasses," Herbage Abstracts, Vol. 40, No. 2, 1970, pp. 116-121.

[30] I. Rhodes, R. P. Collins and D. R. Evans, "Breeding White Clover for Tolerance to Low Temperature and Grazing Stress,” Euphytica, Vol. 77, No. 33, 1994, pp. 239242. doi:10.1007/BF02262636

[31] W. R. Fehr, "Principles of Cultivar Development: Crop Species. Vol. 1: Theory and Technique,” Iowa State University, Ames, 1993, p. 563.

[32] S. J. Helland and J. B. Holland, "Blend Response and Stability and Cultivar Blending Ability in Oat," Crop Science, Vol. 41, No. 6, 2001, pp. 1689-1696. doi:10.2135/cropsci2001.1689

[33] H. P. Singh, D. R. Batish and R. K. Kohli, "Autotoxicity: Concept, Organisms and Ecological Significance," Critical Reviews in Plant Sciences, Vol. 18, No. 6, 1999, pp. 757-772. doi:10.1016/S0735-2689(99)00399-8

[34] M. Sanderson, "Stability of Production and Plant Species Diversity in Managed Grasslands: A Retrospective Study," Basic and Applied Ecology, Vol. 11, No. 3, 2010, pp. 216-224. doi:10.1016/j.baae.2009.08.002

[35] M. D. Casler and P. N. Drolsom, "Yield Testing CoolSeason Forage Grasses in Pure Stands vs. Binary Mixtures with Alfalfa,” Crop Science, Vol. 24, No. 3, 1984, pp. 453-456. doi:10.2135/cropsci1984.0011183X002400030005x

[36] J. Hill, "Breeding Components for Mixture Performance," Euphytica, Vol. 92, No. 1-2, 1996, pp. 135-138. doi:10.1007/BF00022838

[37] P. Annicchiarico and S. Proietti, "White Clover Selected for Enhance Competitive Ability Widens the Compatibility with Grasses and Favours the Optimization of Legume Content and Forage Yield in Mown Clover-Grass Mixtures," Grass Forage Science, Vol. 65, No. 3, 2010, pp. 318-324. doi:10.1111/j.1365-2494.2010.00749.x 